\title{
PLASTIC SKELETON SHIFTING CRITERIA FOR ACCEPTANCE EVALUATION OF STEEL MOMENT RESISTING FRAMES
}

\author{
塑性骨格曲線移動則による鋼構造ラーメン骨組の性能判定
}

\author{
Praveen KHANDELWAL* and Kenichi OHI** \\ カンデルワル プラヴィーン, 大井謙一
}

\begin{abstract}
This paper focuses on damage simulation for a simplified acceptance evaluation of multi-degree-of-freedom moment resisting steel frames. A global reduced analysis procedure, previously proposed by the authors, is utilised for seismic demand prediction at local (member) level, which are compared with a detailed member based analysis. A plastic skeleton shift damage model is used to predict member cyclic plastic deformation capacity, from the monotonic capacity. The shift parameter is calibrated using the past experimental results on constant amplitudes cyclic loading for $\mathrm{H}$-shaped steel sections. For simplicity of acceptance check, the deformation level corresponding to member strength deterioration, below plastic limit, is considered as critical. A six-storey two-bay frame is studied for three ground motions and an acceleration impulse. This study indicates that the proposed simple methods can serve as a good tool for seismic acceptance evaluation for practical purposes.
\end{abstract}

Keywords: acceptance evaluation, cumulative damage, inelastic response, planar steel moment resisting frame 性能評価、累積損傷、弾塑性応答、鋼構造平面ラーメン

\section{INTRODUCTION}

The need for seismic performance evaluation of existing and new constructions has come into focus following damage and collapse of numerous structures during recent earthquakes. Recognising the same, the building design codes in USA [1] and Japan [2] have been revised to introduce explicit concepts of performance based designs. At present, it may be fair to say that simple and efficient methods for performance evaluation have not been adequately developed. With these considerations, a design friendly reduced analysis (RA) approach for ultimate (global) demand evaluation of multi-degree-of-freedom steel moment resisting frames was proposed by the authors [3]. This paper focuses on a simplified approach for damage simulation and acceptance evaluation. The seismic demands of critical members are evaluated from the global demands predicted by RA and are compared with a detailed member based analysis. The member deformation capacity under cyclic loading is determined from the monotonic loading capacity by using a plastic skeleton shift damage model. Application of the proposed methods is studied for a six-storey twobay frame for three ground motions and an acceleration impulse.

\section{DEMAND EVALUATION BY REDUCED ANALYSIS}

(1) OUTLINE OF REDUCED ANALYSIS [3]

A brief overview of a member hysteresis based analytical procedure and reduced analysis method is shown in Fig.1 and Fig. 2, respectively for understanding the simplifications in RA. In RA, a preliminary analysis based on first order reliability method and a simple equivalent-static model of seismic loads is performed. The random equivalent-static force is given by a linear combination of deterministic modal force vectors and the random multiplier to each modal load profile, having zero-mean and standard deviation proportional to effective modal mass times the spectral acceleration. Using this model, the important collapse modes are judged from consideration of reliability index $(\beta)$ and probabilistic network evaluation technique. Lower is the $\beta$, more important is the failure mode. The virtual work equations of only important collapse modes are used to arrange a global yield polyhedron model of the frame, which represents the elastic-perfectly-plastic idealisation of the global restoring force characteristics. In the inelastic state during dynamic analysis, the plastic components of deformation for the important collapse modes are computed by the normality rule on the yield polyhedron.

\section{(2) LOCAL (MEMBER) PLASTIC DEFORMATION DEMAND}

The local deformation demands are studied on a six-storey two-bay frame [4] as shown in Fig. 3. The columns and beams are composed of $\mathrm{H}$-shaped and I-shaped steel members, respectively. The cross-section details are shown in Fig. 4 and Table 1. The storey height is $3.75 \mathrm{~m}$ and span of each bay is $6 \mathrm{~m}$. The modulus of elasticity and yield stress for steel is taken as $205 \mathrm{GPa}$ and $235 \mathrm{Mpa}$, respectively. The total weight of the frame is $3326.4 \mathrm{KN}$ and yield base shear coefficient is 0.11 . The fundamental natural period is 2.57 seconds and the other details are given in reference [3]. The collapse modes under horizontal loads have been enumerated and are shown in Fig. 5. The important failure modes are listed in Table 2. The frame is analysed for El Centro (NS), 1940, Hachinohe (EW), 1968, Fukiai

\footnotetext{
* Graduate Student, University of Tokyo

** Assoc. Prof., Institute of Industrial Science, University of Tokyo, Dr. Eng.
} 

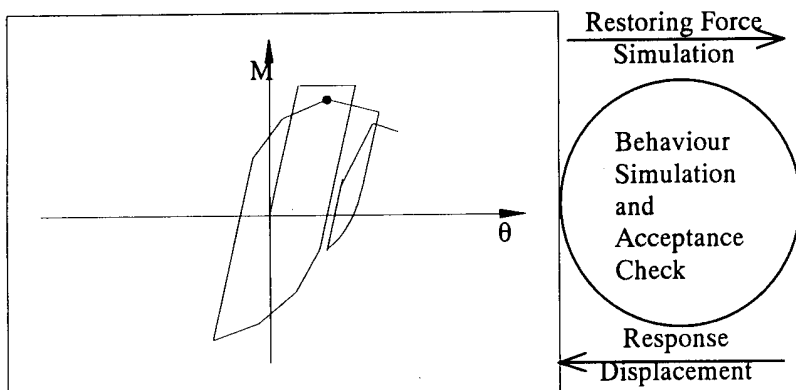

Table 1 - Member Properties

\begin{tabular}{|l|r|r|r|r|r|}
\hline $\begin{array}{l}\text { Mem. } \\
\text { ID }\end{array}$ & $2 \mathrm{~b} / \mathrm{h}$ & $\begin{array}{l}\theta_{p} \text { (rad.) } \\
\left(\mathrm{M}_{\mathrm{p}} \mathrm{L} / 6 \mathrm{EI}\right)\end{array}$ & $\mathrm{b} / \mathrm{t}_{\mathrm{f}}$ & $\mathrm{d} / \mathrm{t}_{\mathrm{w}}$ & $\mathrm{L} / \mathrm{r}_{\mathrm{y}}$ \\
\hline 1 & 1.0 & 0.01018 & 6.15 & 16.75 & 92.68 \\
\hline 2 & 1.0 & 0.00732 & 6.88 & 19.79 & 67.10 \\
\hline 3 & 1.0 & 0.00809 & 6.67 & 18.89 & 74.05 \\
\hline 4 & 1.0 & 0.00669 & 7.06 & 20.60 & 61.64 \\
\hline 5 & 1.0 & 0.00615 & 7.43 & 22.50 & 56.85 \\
\hline 6 & 0.5 & 0.00647 & 6.67 & 43.37 & 151.92 \\
\hline 7 & 0.5 & 0.00718 & 6.69 & 41.83 & 158.41 \\
\hline 8 & 0.5 & 0.00785 & 6.96 & 40.93 & 169.11 \\
\hline 9 & 0.5 & 0.00859 & 7.01 & 39.24 & 179.07 \\
\hline 10 & 0.5 & 0.01081 & 6.12 & 35.55 & 222.63 \\
\hline
\end{tabular}

Fig. 1 Member Hysteresis Based Analytical Models (Deterioration and Simultaneous Acceptance Check)

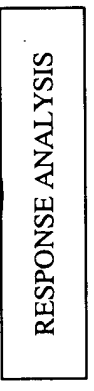

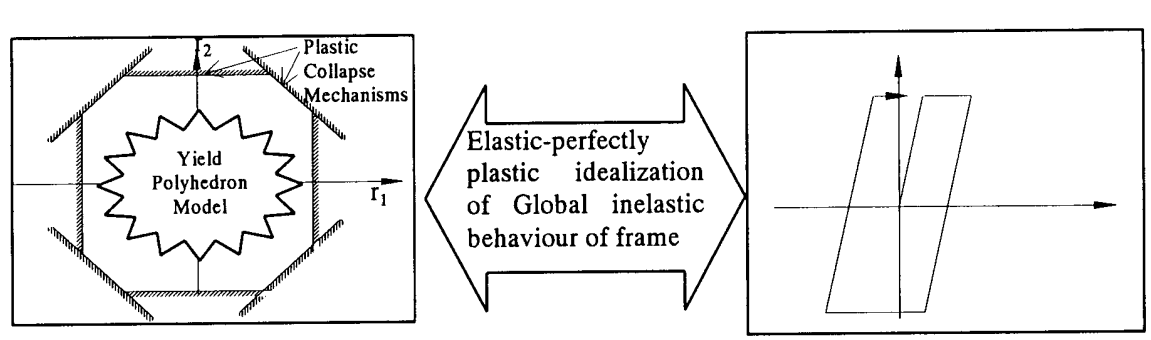

Global yield polyhedron in modal restoring force space
Simplified Model for Response Analysis without Deterioration

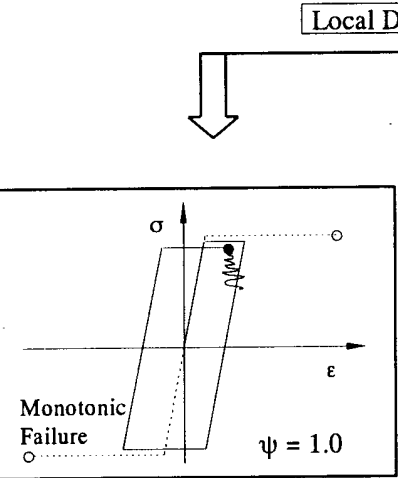

Severely Cumulative

(Kato-Akiyama)
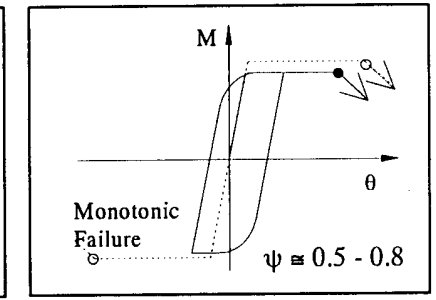

Moderately Cumulative e.g.

member resistance

deterioration due to buckling
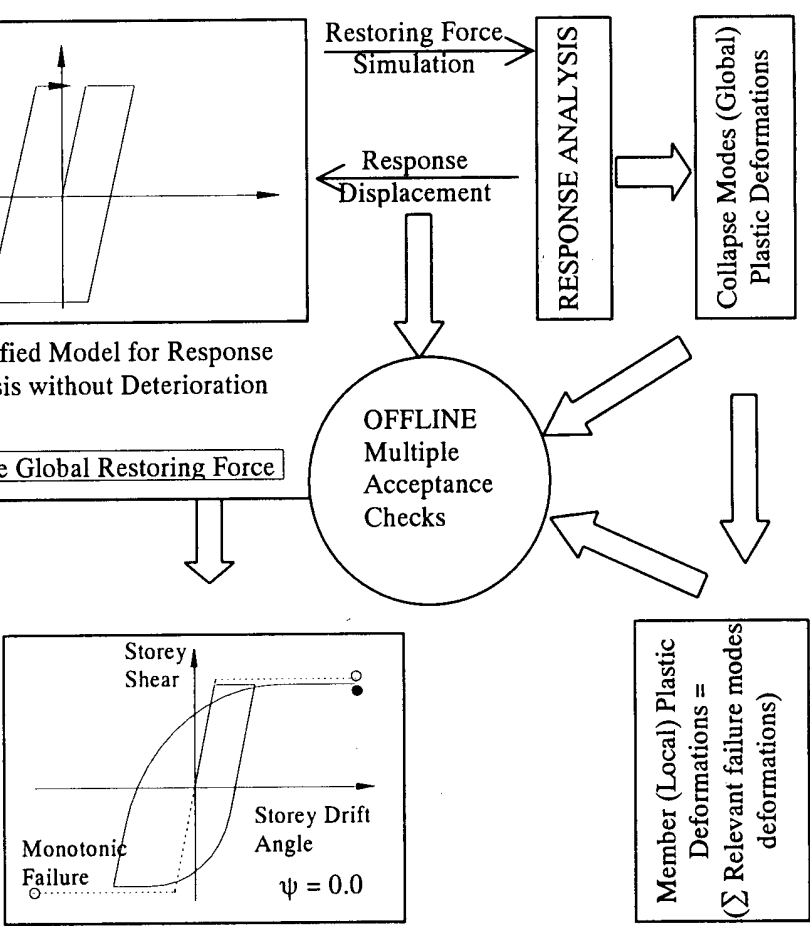

Non-cumulative e.g. peak drift criteria for non-structural members

Fig.2 Simplified Reduced Analysis Method for Damage Simulation and Acceptance Evaluation

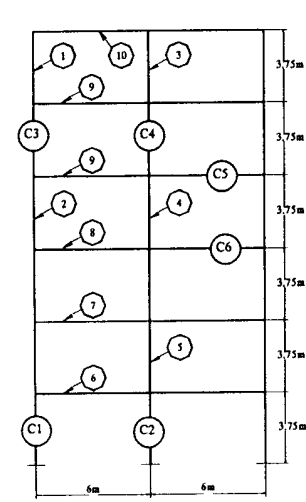

Fig.3 Six-Storey Two-Bay Frame

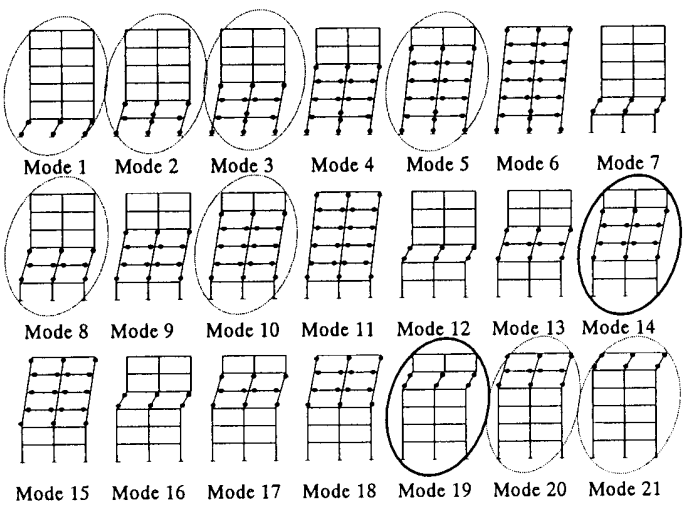

Fig. 5 Collapse Modes for six-storey two-bay frame

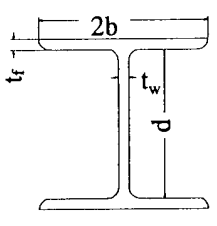

Fig. 4 Member Cross Section
Table 2 Important Failure Modes

\begin{tabular}{|l|l|}
\hline $\begin{array}{l}\text { Seismic } \\
\text { Motion }\end{array}$ & Failure Modes \\
\hline El Centro & $1,10,14,17,19,20$ \\
\hline Hachinohe & $2,3,5,14,19,21$ \\
\hline Fukiai & $1,3,10,14,17,19$ \\
\hline Impulse & $1,5,8,14,17,19$ \\
\hline
\end{tabular}

Table 3- Details of Ground Motions

\begin{tabular}{|l|l|l|l|}
\hline $\begin{array}{l}\text { Ground } \\
\text { Motion }\end{array}$ & Earthquake & $\begin{array}{l}\text { PGA* } \\
\text { (in 'g') }\end{array}$ & $\begin{array}{l}\text { Duration } \\
\text { (Sec) }\end{array}$ \\
\hline $\begin{array}{l}\text { El Centro } \\
\text { (NS) }\end{array}$ & $\begin{array}{l}\text { Imperial } \\
\text { Valley, 1940 }\end{array}$ & 0.325 & 10 \\
\hline $\begin{array}{l}\text { Hachinohe } \\
\text { (EW) }\end{array}$ & $\begin{array}{l}\text { Tokachi-Oki, } \\
1968\end{array}$ & 0.186 & 30 \\
\hline Fukiai (NS) & $\begin{array}{l}\text { Hyogoken- } \\
\text { Nanbu, 1995 }\end{array}$ & 0.700 & 20 \\
\hline
\end{tabular}

${ }^{*}$ Peak Ground Acceleration (in gravity acceleration) 
(NS), 1995 ground motions and an impulse of $0.75 \mathrm{~m} / \mathrm{sec}$ velocity. The details of the ground motions are shown in Table 3.

The plastic deformation history of each important collapse modes is computed in the response analysis. The plastic rotation history of the plastic hinges is calculated by the compatibility equation. If the plastic hinge belongs to some collapse modes, the summation of each plastic deformation history will be considered as the response history of the plastic hinge. As a matter of simplification, the collapse modes with cumulative plastic rotation, in one side, more than $1 / 200$ radian are considered important for studying member deformation demand and these are listed in Table 4. As a further simplification, the members whose cumulative plastic rotation exceeds 0.01 radian are considered important to be studied for acceptance check. The value of 0.01 radian is selected considering that yield value of various member rotations (refer Table 1) range from 0.006 to 0.01 radians. In general, the members marked from $\mathrm{Cl}$ through $\mathrm{C} 6$ in Fig. 3 have undergone cumulative plastic rotations, in one side, in excess of 0.01 radians. The deformation demands of these members have been compared with a member based elastic-plastic analysis made using a computer program DIANA [5] to validate results of RA. The envelopes of cumulative plastic deformation and maximum plastic deformation obtained from RA and Diana have been plotted in Fig. 6 and 7, respectively. It can be seen that the demand prediction by RA is fairly good for practical purposes.

Table 4 Cumulative Plastic Rotation (> 1/200) of

Important Failure Modes (RA)

\begin{tabular}{|c|c|c|c|}
\hline $\begin{array}{l}\text { Seismic } \\
\text { Motion }\end{array}$ & $\begin{array}{l}\text { Failure } \\
\text { Mode } \\
\text { ID }\end{array}$ & $\begin{array}{l}\text { Positive } \\
\text { Rotation } \\
\sum_{+} \Delta \theta_{p, R A}\end{array}$ & $\begin{array}{l}\text { Negative } \\
\text { Rotation } \\
\sum \Delta \theta_{p, R A}\end{array}$ \\
\hline \multirow{3}{*}{ El-centro } & 19 & 0.0174 & -0.0219 \\
\hline & 14 & 0.0065 & -0.0002 \\
\hline & 1 & 0.0010 & -0.0065 \\
\hline \multirow[t]{4}{*}{ Hachinohe } & 14 & 0.0323 & -0.0185 \\
\hline & 19 & 0.0284 & -0.0531 \\
\hline & 5 & 0.0012 & -0.0055 \\
\hline & 2 & 0.0000 & -0.0057 \\
\hline \multirow[t]{4}{*}{ Fukiai } & 19 & 0.0306 & -0.0956 \\
\hline & 14 & 0.0015 & -0.0119 \\
\hline & 17 & 0.0110 & 0.0000 \\
\hline & 1 & 0.0015 & -0.0208 \\
\hline \multirow[t]{3}{*}{ Impulse } & 19 & 0.0000 & -0.0302 \\
\hline & 14 & 0.0010 & -0.0093 \\
\hline & 1 & 0.0005 & -0.0130 \\
\hline
\end{tabular}
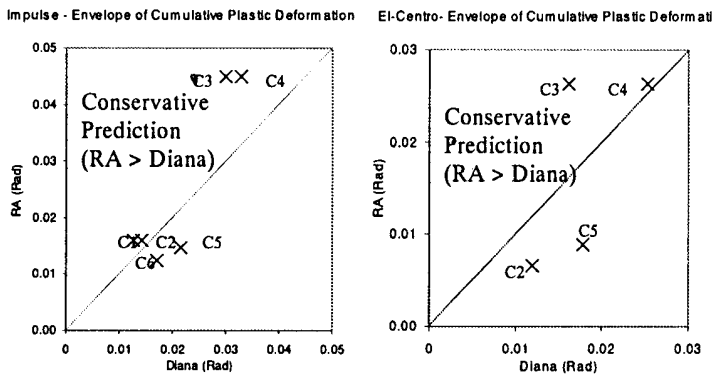

Figure 6 Envelopes of Cumulative Plastic Deformation
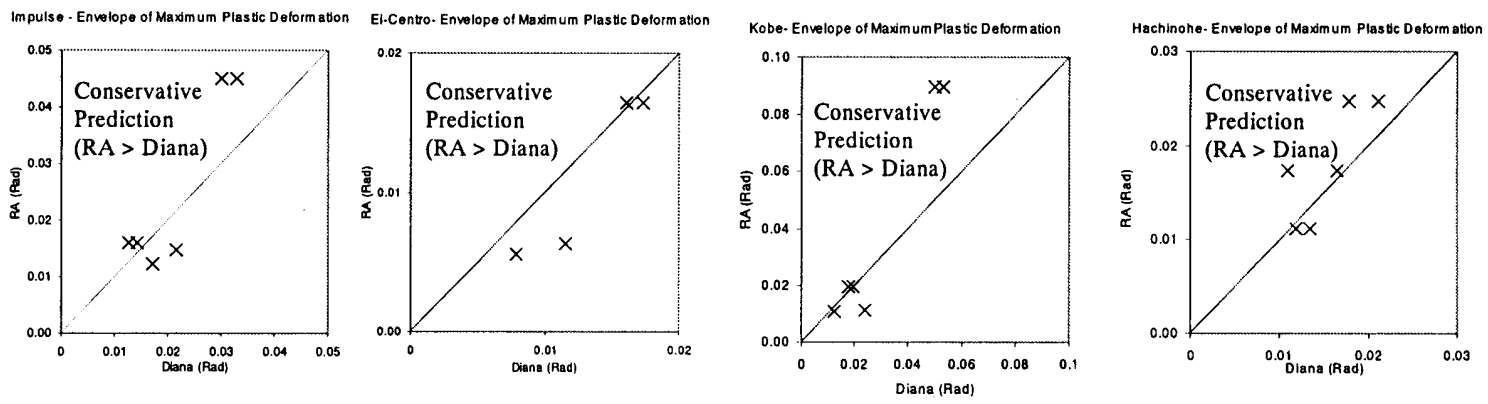

Figure 7 Envelopes of Maximum Plastic Deformation

\section{DAMAGE SIMULATION BY SKELETON SHIFT MODEL}

Damage may be defined as an unfavourable phenomenon/ state wherein a structure does not meet prescribed objective, which is usually related to non-restorable/ permanent plastic deformations that may adversely affect the performance.

The deformation demands in RA are computed for elastic-perfectly plastic idealisation of global restoring force characteristics i.e. without incorporation of deterioration/ degradation effects. Initiation of such effects is then simulated using a skeleton shift model on the deformation history and multiple offline acceptance checks are carried out. The objective of offline acceptance checks is only to detect the initiation of deterioration wherein deterioration characteristics are not so severe such as due to buckling, etc. The simplified analysis with offline acceptance checks (Fig. 2) is not suitable if the deterioration characteristics are severe such as due to brittle failure and/or the sequence of deterioration/yielding is to be traced. Under such conditions, detailed analytical models incorporating simultaneous acceptance checks (Fig. 1) should be used.

A brief description of the skeleton shift model and various damage simulations is provided in the following sections.

\section{(1) SKELETON SHIFT MODEL}

A skeleton shift model $[6,7,8]$ was originally developed to simulate hysteretic behaviour of steel members focusing on non-stationary (or history dependent) change of plastic resistances. The model was considered to represent the uniaxial stress-stain hysteretic characteristics of steel under cyclic reversals. It was applied to axial force-deformation hysteretic characteristics of bar springs in multi-spring joint model, used to represent plastic zones in the beam-columns. Fig. 8 shows the skeleton shift hysteresis rule for the bar springs. When plastic deformation along one side of the skeleton occurs, the target point in the loading side moves together with the loading point, and at the same time, the other side skeleton curve is shifted to the loading direction as much as $\psi$ times the plastic deformation. Strictly, $\psi$ should be a non-linear function of the deformation history. For simplicity and practical application, shifting of skeleton curve is taken as proportional to the movement along plastic skeleton, which is not likely to induce significant errors. The parameter $\psi$ may range from 0 to 1 for steel
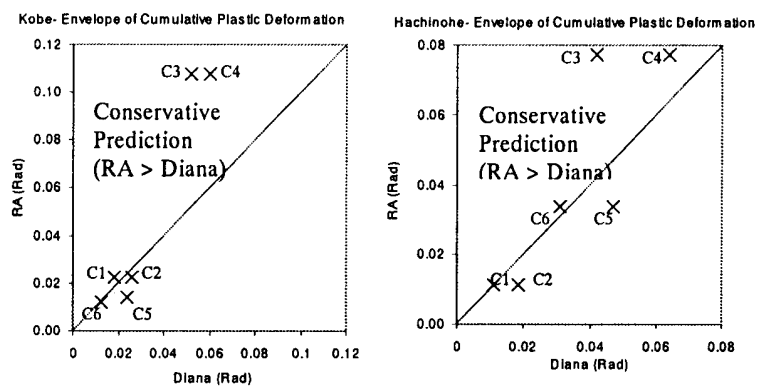
members. Fig 9 and Fig. 10 compare the test and model results, for a boxsection beam-column (width/thickness $=40$ ), for monotonic loading and for El-Centro (NS), 1940 seismic wave (PGA = $0.35 \mathrm{~g}$ ) [7]. Thus, this kind of hysteresis model including deterioration can be used for the simultaneous acceptance check shown in Fig. 1.

For energy absorption capacity evaluation, decomposition of hysteretic curve into the skeleton part and Bauschinger part has been proposed in reference [9] for round shape steel rods subjected to bending, wherein the skeleton part can be predicted by analytical methods and Bauschinger part can be estimated by empirical relationships. In our view, skeleton shift model is relatively simple, and design friendly, as it uses a single shift parameter to simulate both parts.

In this study, only the plastic component of the deformation is used for the damage simulation and to ascertain if member strength degradation below Mp occurred. The procedure is illustrated in Fig. 11.

\section{(2) DETERIORATION-FREE AMPLITUDE IN LOCAL/ LATERAL BUCKLING FAILURE OF BEAM-COLUMNS}

The shift parameter $\psi$ can be calibrated from the deterioration observations in the constant plastic deflection amplitude cyclic loading tests If $\theta_{\mathrm{a}}$ is the constant plastic rotation amplitude (refer Fig. 12), then the cyclic cumulative skeleton plastic rotation, on each loading side, will form a geometric progression. Following relationship is obtained for $N(z 1)$ integer cycles:

Negative side:

${ }_{p} \theta_{a}(1+\psi)+{ }_{p} \theta_{a}(1+\psi) \psi^{2}+\ldots+{ }_{p} \theta_{a}(1+\psi) \psi^{2(N-1)}={ }_{p} \theta_{a} \frac{\left(1-\psi^{2 N}\right)}{(1-\psi)}$

Positive side, if $(1+\psi) \psi^{2 N-1}<1$ :

${ }_{p} \theta_{a}+{ }_{p} \theta_{a}(1+\psi) \psi^{1}+\ldots+{ }_{p} \theta_{a}(1+\psi) \psi^{2 N-3}={ }_{p} \theta_{a} \frac{\left(1-\psi^{2 N-1}\right)}{(1-\psi)}$

Positive side, if $(1+\psi) \psi^{2 N-1}>1$ :

${ }_{p} \theta_{a}+{ }_{p} \theta_{a}(1+\psi) \psi^{1}+\ldots+{ }_{p} \theta_{a}(1+\psi) \psi^{2 N-1}-{ }_{p} \theta_{a}={ }_{p} \theta_{a} \psi \frac{\left(1-\psi^{2 N}\right)}{(1-\psi)}$

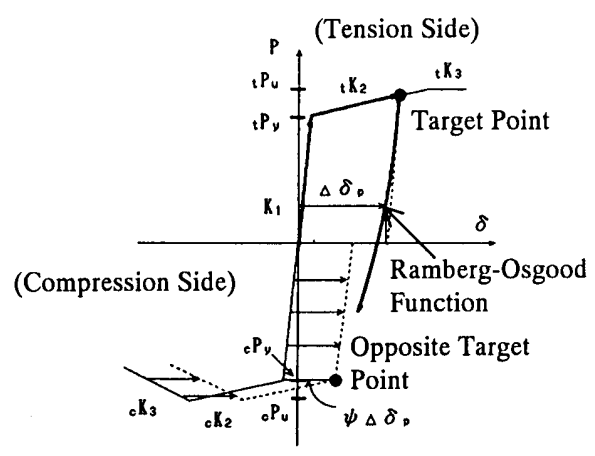

Fig. 8 Skeleton-Shift Hysteresis Rule for Bar Springs
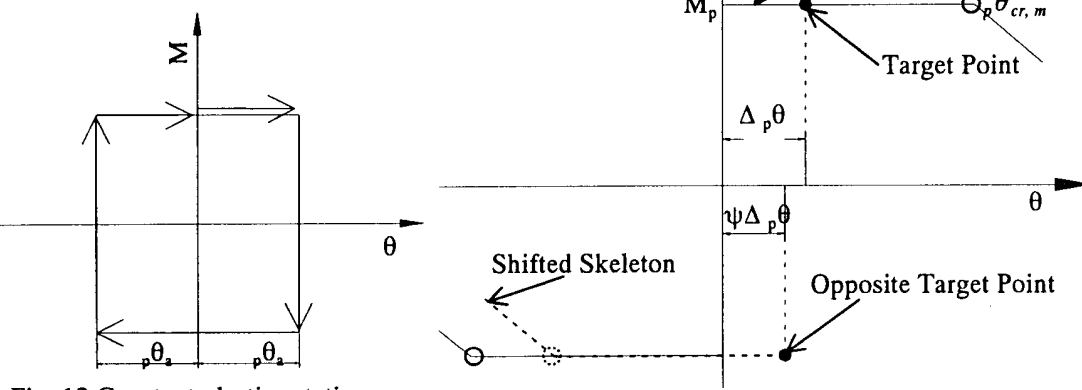

Fig. 12 Constant plastic rotation Cyclic Hysteresis Loop
Fig. 9 Moment vs. Rotation Relationship After Meng, Ohi, Takanashi [7]
Fig. 11 Plastic Skeleton Shift Model for Damage Simulation
For $\psi \leq 1$, the maximum value of cumulative skeleton plastic rotation $\left(\sum_{s} \theta\right)$ will be on negative side i.e.

$$
\sum_{s} \theta={ }_{p} \theta_{a} \frac{\left(1-\psi^{2 N}\right)}{(1-\psi)}
$$

For large values of N, Eq. (1) can be approximated as:

$$
\sum_{s} \theta=\frac{p_{p} \theta_{a}}{(1-\psi)} \Rightarrow \psi \approx 1-\frac{p_{p} \theta_{a}}{\sum_{s} \theta}
$$

Eq. (2) is used to calibrate $\psi$ from the past experimental result [10] on $\mathrm{H}$ shaped cross sections (SS-41, SM-50). In these tests, critical deflection amplitude in constant deflection amplitude cyclic loading were obtained, up to which load-deflection hysteresis loops are stable. Such an amplitude is termed as deterioration-free amplitude hereafter. Fig.13 shows one such hysteresis loop [10]. Table 5 lists critical plastic rotation capacity $\left[R_{c}=\right.$ $\left.\left(\theta / \theta_{\mathrm{p}}\right)_{c}-1\right]$, normalised to yield rotation, for the tested members. Experimental studies [11] on similar cross-sections were carried out to determine the plastic rotation capacity under monotonic loading, with moment gradient, which can be idealised as shown in Fig. 14. The plastic rotation capacity corresponding to maximum moment $\left(M / M_{p}=\tau\right)$ is shown by $R_{m}$ in Table 5 . The parameter $\psi$ can be obtained as follows:

$$
\psi \approx 1-\frac{R_{c}}{R_{m}}
$$

Figure 15 shows the $\psi$ value $\mathrm{v} / \mathrm{s}$ slenderness ratio $\left(\mathrm{L} / \mathrm{r}_{\mathrm{y}}\right)$ for steel grades SS-41 and SM-50. Within this data, $\psi$ varies from about 0.5 to 0.8 . The same range of $\psi$ may hold good for $\mathrm{n}_{\mathrm{y}}$ (ratio of applied axial load to yield axial load) ranging from 0.0 to 0.4 [7]. As a conservative measure for damage simulation, $\psi=0.8$ is adopted. At higher order of $n_{y}$, $\psi$ may be taken conservatively as 1.0 . The grade of steel doesn't seem to influence $\psi$.

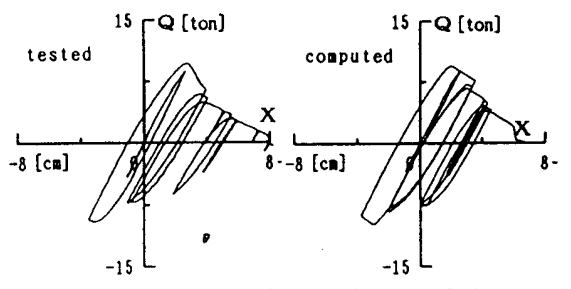

Fig. 10 Hysteresis Curve of Beam-Column (Shift Parameter $\psi=0.8$ ) After Meng, Ohi, Takanashi [7]

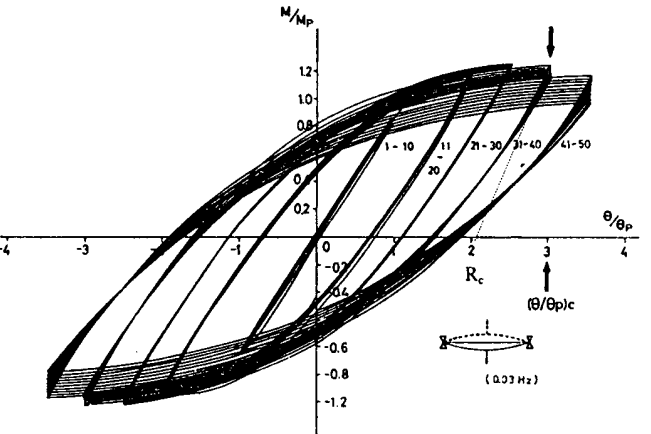

Fig. 13 Hystersis Loops, Test DG-130-4 After Udagawa, Takanashi, Tanaka [10] 


\section{(3) LOW-CYCLE FATIGUE}

Idea of shift parameter $\psi$ can also be used to simulate low cycle constant plastic strain fatigue characteristics, of the kind proposed by Coffin and Manson [12].

$$
\varepsilon_{p} N^{k}=C
$$

where, $\varepsilon_{p}$ is the plastic strain amplitude (peak to peak) and $k$ and $C$ are material constants. The constant $k$ is approximately taken as 0.5 and the constant $C$ can be obtained by putting $\varepsilon_{p} / 2=\varepsilon_{l, m}$ for $N=1 / 4$ cycles, where $\varepsilon_{l, m}$ is the monotonic plastic strain capacity. Eq. (4) can be written as:

$$
r_{c-m} N^{0.5}=1
$$

where, $r_{c-m}=\varepsilon_{p} / \varepsilon_{l, m}$.

For the purpose of comparison, the ratio of constant cyclic plastic rotation to cumulative skeleton plastic rotation, in $\mathrm{N}$ cycles, can be obtained from Eq. (1) as:

$$
r_{s}=2 \theta_{a} \theta_{a} / \sum_{s} \theta=2(1-\psi) /\left(1-\psi^{2 N}\right)
$$

Eqs. (5) and (6) have been calibrated such that for $\mathrm{N}=1$ cycle:

$$
r_{c-m}=r_{s}(\psi=1)=1
$$

Fig. 16 compares Eq. (6) and Eq. (7) for $N(\geq 1)$. However, for $N=1 / 4$ cycles $r$ is shown as 2 for the sake of completeness. It appears that certain $\psi$ values can simulate fatigue behaviour for a given range of $r$ and $N$ e.g. $\psi=0.8$ apparently seem to simulate fatigue behaviour for $N \leq 10$. However, while combining fatigue acceptance with RA it should be noted that RA provides only global plastic deformation history and local partial yielding of the frame is ignored. Accordingly, $\psi$ should be increased to compensate for the same to account for effects such as micro crack propagation, etc.

\section{(4) OTHER SIMPLIFIED DAMAGE SIMULATIONS}

\section{It may be interesting to note that:}

For $\psi=0$, skeleton demand is not cumulated so far as deformation remains within the past peak values. This corresponds to acceptance evaluation by maximum deformation criteria. Performance of non-structural members may be checked against such criteria (Fig. 2).

For $\psi=1$, each plastic deformation increment contributes to the skeleton

\begin{tabular}{|c|c|c|c|c|c|c|}
\hline $\begin{array}{l}\text { Steel } \\
\text { Grade }\end{array}$ & Mem. & Specimen $^{1}$ & $\mathrm{~L} / \mathrm{r}_{\mathrm{y}}$ & $\mathrm{R}_{\mathrm{c}}{ }^{\prime}$ & $\mathrm{R}_{\mathrm{m}}^{2}$ & $\psi$ \\
\hline \multirow[t]{11}{*}{ SS-41 } & \multirow{9}{*}{$\begin{array}{l}\text { H } 200 \times 100 x \\
5.5 \times 8\end{array}$} & DG-110-1 & 51.2 & 2.5 & 6.69 & 0.63 \\
\hline & & DG-110-2 & 51.3 & 2.0 & 6.67 & 0.70 \\
\hline & & DG-130-4 & 62.5 & 2.0 & 4.70 & 0.57 \\
\hline & & DG-130-7 & 62.6 & 2.0 & 4.69 & 0.57 \\
\hline & & DG-130-8 & 62.4 & 2.0 & 4.71 & 0.58 \\
\hline & & DG-130-16 & 62.1 & 2.1 & 4.75 & 0.56 \\
\hline & & DG-130-20 & 61.9 & 2.4 & 4.78 & 0.50 \\
\hline & & DG-150-2 & 70.0 & 1.7 & 3.94 & 0.57 \\
\hline & & DG-170-3 & 81.7 & 1.0 & 3.00 & 0.67 \\
\hline & \multirow{2}{*}{$\begin{array}{l}\text { H } 100 \times 100 \times \\
5.5 \times 8\end{array}$} & DGC-120-2 & 50.8 & 3.3 & $14.6^{\circ}$ & 0.77 \\
\hline & & DGC-150-2 & 63.6 & 3.1 & $8.9^{\circ}$ & 0.65 \\
\hline \multirow[t]{4}{*}{ SM-50 } & \multirow{4}{*}{$\begin{array}{l}\text { H } 100 \times 100 x \\
6 \times 8\end{array}$} & DGH-110-2 & 52.3 & 1.3 & 3.40 & 0.62 \\
\hline & & DGH-130-2 & 61.9 & 1.1 & 3.05 & 0.64 \\
\hline & & DGH-150-2 & 71.6 & 1.0 & 2.25 & 0.56 \\
\hline & & DGH-170-2 & 80.9 & 0.5 & 1.30 & 0.62 \\
\hline
\end{tabular}
demand. This corresponds to Kato-Akiyama model of acceptance evaluation by cumulative plastic deformation criteria (Fig. 2)

Table 5 Calibration of $\psi$ value

See Reference [10] for details. * Higher value than shown is expected.

${ }^{2} R_{m}$ (DG series) $=5770 x\left(L / r_{y}\right)^{-1.71}[11] ; R_{m}$ (DGC and DGH series) [11]

\section{ACCEPTANCE CHECK}

Load deformation relation under monotonic loading is evaluated as shown in Fig. 14 [13]. The strength ratio $(\tau)$ of a member is determined from the consideration of local buckling and flexural torsional buckling after Akiyama's empirical formulas. The ratio of rigidity in the strain hardening range to elastic rigidity is taken as 0.03 for simplicity. For the purpose of acceptance check, load-deformation curve is simplified and assumed to consist of elastic, perfectly plastic and degrading zones as shown in Fig. 14. In actual behaviour, degradation in member strength would begin after attaining maximum value $\mathbf{M}_{\mathrm{m}}$. In this paper, however, degradation is assumed when member strength falls below $M_{p}$ and the cumulative plastic rotation capacity is limited to $\left({ }_{p} \theta_{c r, m}=R_{p} \theta_{p}\right)$. It may be noted that the definition of limiting value under monotonic loading $\left({ }_{p} \theta_{c r, m}\right)$ may not be unique and a different definition based on other considerations such as absorbed plastic energy, etc. may also be adopted. As a conservative measure, a member is considered acceptable if there is no initiation of member strength degradation (below $M_{p}$ ) i.e. the cyclic

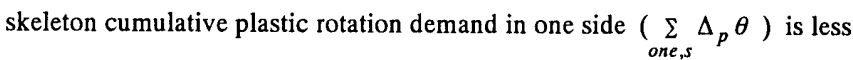
than the monotonic plastic rotation capacity $\left({ }_{p} \theta_{c r, m}\right)$.

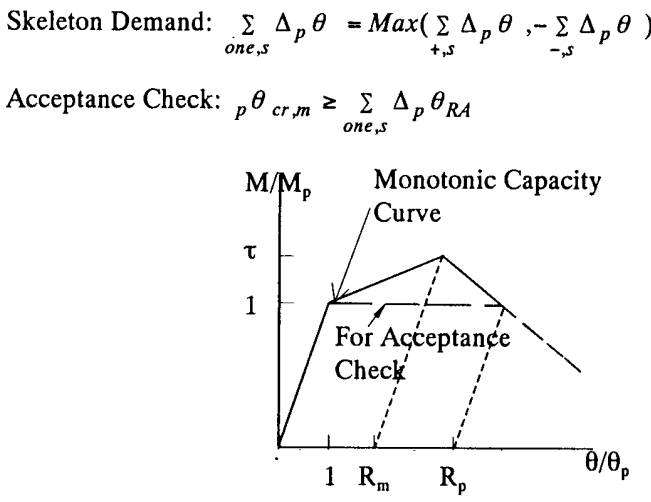

Fig. 14 Load-Deformation Idealisation

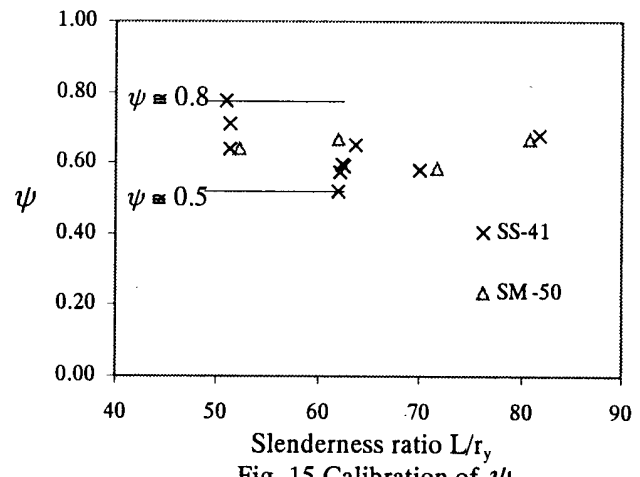

Fig. 15 Calibration of $\psi$

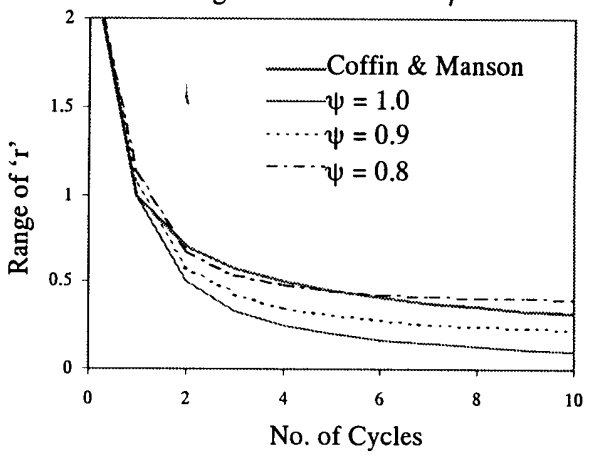

Fig. 16 Fatigue Simulation 
For $\psi=0$, the skeleton demand $\left(\sum_{0 \text { e }} \Delta_{p} \theta\right)$ will be same as the maximum plastic rotation demand. Table 6 compares the capacity and demand for critical members for $\psi=0.8$ and $\psi=1.0$. It is seen that the demand envelope is not sensitive to $\psi$ values and $\psi=1.0$ can be adopted in the present case. Insensitiveness of the demand envelope to $\psi$ is due to the fact that there are only a few cycles of large plastic deformation in the chosen example. However, it should be noted that skeleton plastic deformation demand might be sensitive to selected $\psi$ value, when there are many cycles of relatively small plastic deformations. Under such situations, adoption of higher $\psi$ may lead to quite conservative scenario.

It can be seen from Table 6 that all the member are in the acceptable state, from the standpoint of structural safety itself, because the frame studied is composed of relatively stocky members. The global and local demands obtained from RA can also be used to judge the performance against the limiting values of interstorey drift angles, drift angle capacities of local connections and non-structural elements, etc indicated in the design codes [14,15]. For example, $\theta_{p \max }$ exceeds $1 / 15$ radian to Kobe Earthquake (Fig. 7), which is not acceptable from the safety of nonstructural elements e.g. curtain walls, etc.

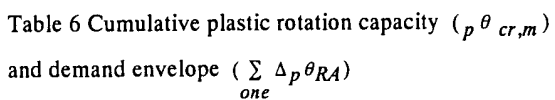

\begin{tabular}{|l|c|c|c|}
\hline $\begin{array}{l}\text { Member } \\
\text { ID }\end{array}$ & $\left(p \theta_{c r, m}\right)$ & $\begin{array}{l}\psi=0.8 \\
\left(\sum_{\text {one }} \Delta_{p} \theta_{R A}\right)\end{array}$ & $\begin{array}{l}\psi=1.0 \\
\left(\sum_{\text {one }} \Delta_{p} \theta_{R A}\right)\end{array}$ \\
\hline $\mathrm{C} 1$ & 0.22866 & 0.0223 & 0.0225 \\
\hline $\mathrm{C} 2$ & 0.19959 & 0.0223 & 0.0225 \\
\hline $\mathrm{C} 3$ & 0.20218 & 0.1061 & 0.1075 \\
\hline $\mathrm{C} 4$ & 0.22095 & 0.1061 & 0.1075 \\
\hline $\mathrm{C} 5$ & 0.04837 & 0.0307 & 0.0336 \\
\hline $\mathrm{C} 6$ & 0.04961 & 0.0307 & 0.0336 \\
\hline
\end{tabular}

\section{CONCLUSIONS}

A simple and design friendly, seismic acceptance evaluation procedure is proposed for multi-degree-of-freedom moment resisting frames. The application of proposed ideas is studied for a six-storey two-bay frame for El Centro (NS), Hachinohe (EW), Fukiai (NS) ground motions and an acceleration impulse. Following are the salient features:

1. Local (member) plastic deformations demand obtained from the simplified reduced analysis compare fairly well for practical purposes, with demand predicted by the detailed member based analysis procedures.

2. A plastic skeleton shift model is proposed for damage simulation. The skeleton shift parameter can be suitably adjusted for representing various kinds of damage phenomenon.

3. A comparison of skeleton cumulative cyclic plastic deformation demand with monotonic plastic deformation capacity is used to carry out a simple and conservative acceptance check.

The ideas proposed in this paper lay emphasise on simplicity as well as generality and are expected to help the practising engineer, who has limited resources and analytical tools to carry out his responsibilities.

\section{REFERENCES}

1. FEMA, NEHRP Guidelines for the seismic rehabilitation of buildings, FEMA-273, Federal Energy Management Agency, USA, 1997

2. Building Standard Law of Japan revised, 1998

3. Khandelwal P, Ohi K, Fang P, A Simple Proposal for Ultimate Seismic Demand Evaluation of Moment Resisting Steel Frames, Journal of Structural and Construction Engineering, Trans. of AIJ, No. 545 , July 2001

4. Chen, W.F. and Toma, S., Advanced Analysis of Steel Frames, CRC Press, 1994, pp. 341-343

5. Dynamic Inelastic ANAlysis of steel frames, a private program coded by S.H. Gao and K. OHI, The University of Tokyo, 1987

6. Ohi K, Takanashi K, Meng L, Multi-Spring Joint Model for Inelastic Behaviour of Steel Members with Local Buckling, Bulletin of Earthquake Resistant Structure Research Centre, Institute of Industrial Science, The University of Tokyo, No. 24, pp.105 114, March1991

7. Meng L, Ohi K, Takanashi K, A Simplified Model of Steel Structural Members with Strength Deterioration used for Earthquake Response Analysis, Journal of Structural and Construction Engineering, Trans. of AIJ, No. 437, July 1992 (In Japanese)

8. Chen Y, Ohi K, Takanashi K, The Inelastic Behavior of Square-Box Steel Beam-Columns Subject to Tri-Directional Varying Loads, Journal of Structural and Construction Engineering, Trans. of AIJ, No. 447, May 1993 (In Japanese)

9. Akiyama H, Takahashi M, Shi Z, Ultimate Energy Absorption Capacity of Round-Shape Steel Rods Subjected to Bending, Journal of Structural and Construction Engineering, Trans. of AlJ, No. 475, Sept. 1995 (In Japanese)

10. Udagawa K, Takanashi K, Tanaka H, Restoring Force Characteristics of H-Shaped Steel Beams under Cyclic and Reversed Loadings- Part I: Rotation Capacity of Plastic Hinge under Cyclic Loads at Constant Deflection Amplitudes, Journal of Structural and Construction Engineering, Trans. of AIJ, No. 264, Feb. 1978 (In Japanese)

11. Udagawa K, Saisho M, Takanashi K, Tanaka H, Experiments on Lateral Buckling of $\mathrm{H}$-Shaped Beams Subjected to Monotonic Loadings, Journal of Structural and Construction Engineering, Trans. of AIJ, No. 212, Oct. 1973

12. Frost N.E., Marsh K.J., Pook L.P., Metal Fatigue, Oxford Engineering Science Series, pp.293 300

13. Akiyama, H., Earthquake Resistant Limit State Design for Buildings, University of Tokyo Press, pp.186-191,1985

14. FEMA-350, 2000, Recommended Seismic Design Criteria for New Steel Moment-Frame Buildings, prepared by SAC Joint Venture for the Federal Energy Management Agency, USA.

15. Guidelines on Damage Classification and Restoration Technology of Buildings Damaged by Earthquakes (Steel Structures), Japan Building Disaster Prevention Association, 1995, revised 2001 (In Japanese) 


\section{1.はじめに}

著者らは、文献[3]において、鋼構造ラーメン骨組に対する終局地震 何重効果を、崩壊メカニズム数を重要なもののみに低減した降伏多面 体モデルを用いた応答解析で評価する手法を提案した。そこでは荷重 㕮果は、大局的な応答変位履歷ないし各崩壊機構形の塑性変形履歴の 形で与えられる。本稿では、(1)この荷重効果に対して、鋼構造ラーメ ン骨組の性能が受容できるかどうかの判定を行う手法を示し、(2)鋼構 造ラーメン部材の耐力少化に関連した性能判定を、統一的に表現する 累積損傷クライテリア、について提案する。

\section{2. 简略化応答解析による要求部材望性变形性能 （1）考慮する崩等機構数を低減した简略化応答解析 [3] の概要}

予備解析として弾性地震荷重効果の静的水平荷重モデルとして、古 典的規準モードの荷重基底ベクトルにランダムモード乗数を乗じて 線形結合した荷重モデルを仮定する。モード乗数は零平均とし、標準 偏差は、各次有効質量と設計用加速度応答スペクトル值の積に比例さ せる。骨組の崩壊機構形の信頼性指標值を評価して小さいものを選択 し、また相関の大きな複数の崩壊機構形は統合して、骨組の塑性崩壊 に対する安全領域を降伏多面体モデルで近似する。安全領域の内部で は弾性と仮定し、塑性変位增分の法線則によって応答解析を行う。

\section{（2）要求部材塑性变形性能の評価例}

複数の崩壊機構形毎に塑性変形履歴が算定されるが、その塑性変形 履歴から、適合式により崩壊機構形に属する塑性ヒンジの塑性回転角 復歴を求める。塑性ヒンジが複数の崩壊機構形に属する場合は、それ ぞれの塑性问転角履歷の単純和を塑性ヒンジの応答履歴とみなす。文 献[3]で例題とした 6 層 2 スパン骨組に 4 種の実地震波形を入力した結 果、比較的大きな塑性変形を被る塑性ヒンジの累積塑性変形角ならび に最大塑性変形角について、簡略化応答解析結果（縦軸）と、塑性七 ンジ法による部材レベル弾塑性応答解析結果（横軸）とを図 7 に対照 している。簡略化応答解析で概ね安全側に評価できることが分かる。

\section{3、スケルトン移動型屋歴モデルを利用した受容判定}

上記の簡略化応答解析では、一般化された完全弾塑性挙動が仮定さ れているので、耐力劣化が顕著でない篹罒の応答予測結果が得られる。 その応答履歴を、耐力少化現象も含むスケルトン移動型履歴モデルに 適用して、耐力劣化が顕著になるかについての受容判定を行う。

\section{(1) スケルトン移動型モデルの概要}

歪み硬化、局部座屈・横座屈等の不安定現象による耐力劣化など、 塑性抵抗力の変化を含む履歴モデルとして、第 2 著者の提案になるス ケルトン移動型履歷モデル[6][7][8]を利用する。図 8 に履歴則を示し ているが、1)正側、負側にスケルトン曲線を仮定し、それぞれに目標 点を置く。初期位置としては塑性化開始点に置く。2）載荷点が、一 方のスケルトン曲線の塑性部分をたどると同時に、その上の目標点を 載荷点と一緒に移動する。また塑性移動量の $\Psi$ 倍 (シフト係数)だけ、 逆側のスケルトン曲線を同じ方向に移動する。3)一方のスケルトンか ら除荷した直後は、弾性除荷とするが、逆側のスケルトン上の目標点 に向かう場合は、除荷点と目標点とを結ぶ軟化曲線上をたどる。 単調載荷曲線に適合するようにスケルトン曲線を定め、適切なシフ 、係数を仮定すると、耐力劣化の生じる鉄骨ラーメン部材の履歴曲線 や地震応答性状を追跡できる。(図 9、図 10) スケルトン履歴型モデ ルを用いて部材レベルの忘答解析を行えば、要求性能と性能の受容判 定を同時に行えるが (図 1)、本稿では要求性能については完全弾塑性
モデル、受容判定にのみスケルトン移動型モデルを用いる。(図 2)

\section{（2）耐力劣化の発生しない綵返し变位振幅}

スケルトン移動型履歴モデルでは、塑性抵抗力の変化は、各方向の スケルトン曲線上で経験する塑性変形の総和（スケルトン累積塑性変 形）に依存することになるので、耐力劣化に関わる性能判定は、スケ ルトン累積塑性変形を参照する。また塑性変位一定振幅の繰返し載荷 を行った場合、Nサイクル時のスケルトン累積塑性変形は(1)式で与え られ、 $0<\Psi<1$ のとき、 $N$ を無限大の極限にすると(1)式は(2)式に収斂 する。すなわち、十分小さな振幅で繰り返すと何度繰り返しても、ス ケルトン累積塑性変形はある値以上に進行しない。すなわちスケルト ン移動型履歷則は、耐力劣化の発生しない限界変位振幅が存在するこ とを内包している。宇田川らは H 形断面部材について繰返し載荷実験 を行い、図 13 のような限界振幅を観察している[10]。逆に、実験的 に耐力劣化の生じない限界振幅ならびに単調載荷時の酎力劣化開始 変位が測定されていれば、(3)式によってシフト係数 $\Psi$ を同定すること ができる。宇田川らの実験[10][11]から同定した $\Psi$ の值を表 5 、図 15 に示しているが、シフト係数 $\Psi=0.5$ から 0.8 程度の值となる。

(3) Manson-Coffin 則との対応

低サイクル疲労破壊の場合に用いられる古典的な累積損傷則とし て、Manson-Coffin 則がある。(4)-(6)式、図 16 において、本稿にお けるスケルトン移動型履歴モデルに基づく累積損賃則との比較を行 つているが、ある塑性歪振幅、あるサイクル数の範囲内では、シフト 係数を例えば 0.8 程度に設定して塑性歪履歴に適用すれば、式(4)の Manson·Coffin 則と同等の累積損傷則を表現できるので、この種の低 サイクル疲労のシミュレーションにも利用できる。しかしながら、1） Manson·Coffin 則の形からは、前項のような破壊の生じない塑性歪振 幅は導出することはできないこと、2）本稿で用いているような大局 的応答の塑性履歴は、低サイクル疲労亀裂の成長に関連するような局 所の塑性歪履歴を反映していないこと、に留意すべきである。

\section{（4）その他の简格化された損伤規管}

1） $\Psi=0$ とすると、過去に経験した最大応答変位を超過しない限り、 繰返し塑性変形を受けてもスケルトン累積塑性劦形が進行しない。す なわち、最大応答変位と単調変形能力の比較による性能判定になる。

2） $\Psi=1$ とすると、ある方向の絽り返し塑性変形増分が全てその 方向のスケルトン累積塑性変形に算入されることになり、通常の累積 塑性変形と単調変形能力の比較による加藤 - 秋山型の安全側に簡略 化した性能判定になる。

\section{4. 筒略化応答解析による性能評価例}

2.の簡略化応答解析例で算定された塑性回転角履歴に対して、 $\Psi$ $=1$ ならびに 0.8 を用いて算定したスケルトン累積塑性回転角を表 6 に示しているが、ここで用いた地震応答履歴は綝返し回数が比較的少 なかったため、両者に大きな差は認められなかった。

\section{5. まとめ}

鋼構造ラーメン骨組の崩壊機構数を重要なもののみに低減した降 伏多面体モデルを用いて簡略化応答解析を行い、得られた崩壊機構每 の塑性変形履歷を、塑性ヒンジの塑性回転角履歴に変換する手法を示 し、 6 層 2 スパン骨組の応答解析例によりその適用性を調べた。また 得られた塑性回転角履歴をスケルトン移動型の履歴モデルに適用し てスケルトン累積塑性変形を評価し、単調変形能力と比較することに より部材耐力劣化に関わる受容判定を簡便に行う手法を示した。 